\title{
Development and application of a sensitive, rapid, and reliable immunomagnetic separation-PCR detection method for Cronobacter spp.
}

\author{
Qiming Chen, ${ }^{*}$ Yuanhong Li, ${ }^{*} \dagger$ Tingting Tao, ${ }^{*}$ Xiaomei Bie, ${ }^{*}$ Fengxia Lu, ${ }^{*}$ and Zhaoxin Lu*1 \\ ${ }^{*}$ College of Food Science and Technology, Nanjing Agricultural University, 1 Weigang, Nanjing 210095, People's Republic of China \\ †Department of Public Health, Xuzhou Medical College, 209 Tongshan Road, Xuzhou, Jiangsu 221004, People's Republic of China
}

\begin{abstract}
Cronobacter spp. have been linked to clinical cases of infection in both adults and infants. Enrichment of Cronobacter spp. before detection has been necessary but is quite time consuming. Hence, we sought to develop an immunomagnetic separation (IMS) PCR method that could shorten the time of enrichment before the detection of Cronobacter spp. The polyclonal antibody used in this immunomagnetic separation was prepared based on the outer membrane protein A of Cronobacter sakazakii China Center of Industrial Culture Collection 21560 and had high specificity to the target. The primers used in the IMS-PCR method also showed high specificity. The detection limit of IMS-PCR for pure $C$. sakazakii culture was $5.2 \times 10^{2} \mathrm{cfu} / \mathrm{mL}$. Cronobacter sakazakii in artificially contaminated powdered infant formula (PIF) was also detected at a detection limit of $5.2 \times 10^{2} \mathrm{cfu} / \mathrm{mL}$. After $8 \mathrm{~h}$ of enrichment, the detection limit in PIF was lower than $5.2 \times 10^{1} \mathrm{cfu} / \mathrm{mL}$. An interference test using Escherichia coli in artificially contaminated PIF showed that the IMS-PCR method developed in this study had a good ability to resist interference. Finally, the IMS-PCR method was applied to the detection of Cronobacter in food samples and was shown to be reliable. Thus, this newly developed IMS-PCR detection method was quite sensitive, rapid, and reliable and could be applied to the detection of Cronobacter in foods.
\end{abstract}

Key words: immunomagnetic separation, Cronobacter spp., PCR, polyclonal antibody

\section{INTRODUCTION}

Cronobacter was identified as a new genus in the family Enterobacteriaceae in 2008 (Joshi et al., 2014; Chen et al., 2016). This genus of gram-negative, rod-shaped bacteria consists of 7 species: Cronobacter sakazakii, Cronobacter dublinensis, Cronobacter malonaticus,

Received February 25, 2016

Accepted October 25, 2016.

${ }^{1}$ Corresponding author: fmb@njau.edu.cn
Cronobacter muytjensii, Cronobacter turicensis, Cronobacter universalis, and Cronobacter condimentii (Iversen et al., 2008; Joseph et al., 2012). Infection with Cronobacter spp. can cause meningitis, sepsis, and necrotizing enterocolitis, with a fatality rate of $80 \%$ (Townsend et al., 2008; Healy et al., 2010). Immunocompromised infants and pre-term or low-birth-weight infants under 2 mo of age are especially high-risk groups (Chiang et al., 2012; Li et al., 2013; Álvarez-Ordóñez et al., 2014). Moreover, many infant infection cases have been associated with contaminated powdered infant formula (PIF; Arseni et al., 1987; Friedemann, 2009; Joseph and Forsythe, 2012).

Conventional culture-based methods play an important role in the detection of Cronobacter spp. (Druggan and Iversen, 2009) and have been widely adopted in many standardized detection methods (Wang et al., 2012). These methods usually consist of a series of steps, including nonselective enrichment, selective enrichment, differential plating, and final biochemical confirmation. However, these methods are time consuming (the enrichment steps in particular), have low sensitivity, and are not easy to use (Cawthorn et al., 2008). Polymerase chain reaction and its related technologies have also been widely used in detecting foodborne pathogens. Compared with culture-based methods, PCR methods are more sensitive and have fewer steps. In the case of Cronobacter spp., PCR detection methods based on specific targets such as $16 \mathrm{~S}$ rDNA (Iversen et al., 2004), 16S-23S rDNA internal transcribed spacer (ITS) (Liu et al., 2006), 23S rDNA (Derzelle et al., 2007), tRNAGlu (Hassan et al., 2007), dnaG (Seo and Brackett, 2005), OmpA (Mohan Nair and Venkitanarayanan, 2006), and gluA (Iversen et al., 2007) have been previously reported. In addition, polyclonal and monoclonal antibodies specific to Cronobacter have also been used in detection (Park et al., 2012; Chen et al., 2014; Xu et al., 2014b).

Both PCR and immunological methods can provide rapid, sensitive, specific, and efficient ways to detect Cronobacter. However, the enrichment time necessary before detection is still time-consuming. Immunomagnetic separation (IMS) is a method that isolates cells 
using paramagnetic particles coated with specific antibodies and offers an attractive alternative by shortening the time of enrichment and removing impurities. After separation by IMS, the enriched bacterial cells are detected by PCR. This new combinative method improves the speed, sensitivity, and efficiency of detection (Leon-Velarde et al., 2009). Immunomagnetic separation PCR has been used to detect foodborne pathogens, such as Campylobacter jejuni in chicken samples (Tram et al., 2012), Escherichia coli O157:H7 in raw ground beef (Fedio et al., 2011), Salmonella in raw duck wings (Zheng et al., 2014) and egg products (Jenikova et al., 2000), and Listeria monocytogenes in ready-to-eat foods (Wadud et al., 2010). To our knowledge, no reports are available regarding the detection of Cronobacter spp. by the IMS-PCR method. Only a probe-magnetic separation (PMS) PCR method was reported in a previous study, which used DNA probes conjugated to magnetic beads to isolate genomes of bacterial cells from samples and detect target DNA by PCR (Xu et al., 2014a). However, this method did not include the main species of the Cronobacter genus and lacked application to actual food samples.

In this study, a polyclonal antibody specific to protein outer membrane protein A (ompA) of Cronobacter spp. was prepared and conjugated to magnetic beads. The immunomagnetic beads were used to separate Cronobacter cells to shorten the time of enrichment.
The PCR combined with IMS was used to improve the specificity and sensitivity. Thus, we developed a rapid and reliable IMS-PCR detection method for Cronobacter spp.

\section{MATERIALS AND METHODS}

\section{Bacteria Strains and Growth}

In total, 6 Cronobacter strains and 12 non-Cronobacter strains (Table 1) were tested in this study. These strains were purchased from the American Type Culture Collection (ATCC, Manassas, VA), the China Center of Industrial Culture Collection (CICC, Beijing, China), the China General Microbiological Culture Collection Center (CGMCC, Beijing, China), the National Center for Medical Culture Collections (CMCC, Beijing, China), the Deutsche Sammlung von Mikroorganismen und Zellkulturen (DSMZ, Braunschweig, Germany), and the National Collection of Type Cultures (NCTC, Salisbury, UK). All strains were retrieved from frozen stock cultures and grown in an appropriate broth at $37^{\circ} \mathrm{C}$ at $180 \mathrm{rpm}$.

\section{Preparation of OmpA Protein}

The ompA protein was prepared according to our previous study (Chen et al., 2016). Escherichia coli

Table 1. Specificity of the polyclonal antibody by ELISA and immunomagnetic separation (IMS) PCR

\begin{tabular}{|c|c|c|c|c|}
\hline Strain & $\begin{array}{l}\text { Strain } \\
\text { identification }\end{array}$ & $\mathrm{OD}_{450}{ }^{2}$ & $\mathrm{P} / \mathrm{N}^{3}$ & $\begin{array}{l}\text { IMS-PCR } \\
\text { result }^{4}\end{array}$ \\
\hline Cronobacter muytjensii & CICC 21563 & 1.346 & 5.40 & + \\
\hline Cronobacter malonaticus & DSM 18702 & 1.521 & 6.21 & + \\
\hline Cronobacter turicensis & DSM 18703 & 1.348 & 5.41 & + \\
\hline Cronobacter dublinensis & DSM 18705 & 1.163 & 4.67 & + \\
\hline Cronobacter universalis & NCTC 9529 & 1.454 & 5.83 & + \\
\hline Cronobacter sakazakii (positive control) & CICC 21560 & 1.586 & & + \\
\hline Negative control & & 0.249 & & - \\
\hline Bacillus cereus & AS 1.1846 & 0.264 & 1.06 & - \\
\hline Enterobacter cloacae & ATCC 13047 & 0.432 & 1.73 & - \\
\hline Escherichia coli $\mathrm{BL}_{21}(\mathrm{DE} 3)$ & & 0.553 & 2.20 & - \\
\hline E. coli $\mathrm{DH} 5 \alpha$ & & 0.457 & 1.84 & - \\
\hline Serratia marcescens & CICC 10187 & 0.321 & 1.28 & - \\
\hline Salmonella enteritidis & CICC 21482 & 0.522 & 2.09 & - \\
\hline Listeria monocytogenes & ATCC 15313 & 0.281 & 1.12 & - \\
\hline Escherichia coli & ATCC 35150 & 0.453 & 1.81 & - \\
\hline Bacillus coagulans & CICC 10144 & 0.254 & 1.02 & - \\
\hline Bacillus licheniformis & CICC 23584 & 0.268 & 1.07 & - \\
\hline Staphylococcus aureus & AS 1.2465 & 0.325 & 1.3 & - \\
\hline Pseudomonas fluorescens & AS 1.1802 & 0.259 & 1.04 & - \\
\hline
\end{tabular}

${ }^{1} \mathrm{CICC}=$ China Center of Industrial Culture Collection; DSMZ = Deutsche Sammlung von Mikroorganismen; NCTC $=$ National Collection of Type Cultures; AS = China General Microbiological Collection Center; ATCC $=$ American Type Culture Collection.

${ }^{2} \mathrm{OD}_{450}=$ optical density at $450 \mathrm{~nm}$.

${ }^{3} \mathrm{P} / \mathrm{N}$, positive value/negative value using a ratio of the optical density of the test sample to the negative sample; $\mathrm{P} / \mathrm{N}$ value greater than or equal to 2.1: positive result, $\mathrm{P} / \mathrm{N}$ value less than 2.1: negative result.

${ }^{4}+$, positive result; - , negative result. 
BL21 (DE3) with pET-32a-ompA grown in LuriaBertani (LB) broth with ampicillin $(100 \mu \mathrm{g} / \mathrm{mL})$ at $37^{\circ} \mathrm{C}$ and $180 \mathrm{rpm}$. Isopropyl- $\beta$-D-thiogalactopyranoside was added at a final concentration of $1 \mathrm{~m} M$ when the optical density at $600 \mathrm{~nm}$ value of the culture reached 0.6. After induced expression by isopropyl- $\beta$ D-thiogalactopyranoside at $16^{\circ} \mathrm{C}$ and $180 \mathrm{rpm}$ for 20 $\mathrm{h}$, the bacterial cells were collected by centrifugation $\left(10,000 \times g, 4^{\circ} \mathrm{C}, 10 \mathrm{~min}\right)$, washed with normal saline, and broken by sonication. The supernatant and the precipitation were then separated by centrifugation, and ompA was purified from supernatant by Ni-chelating affinity chromatography.

The process of immunization of male New Zealand rabbits was carried out partly according to the study of Chen and Zhuang (2012). One immunization dose for rabbits was $1 \mathrm{~mL}$ of ompA solution $(0.91 \mathrm{mg} / \mathrm{mL})$ mixed with isovolumetric adjuvant (Freund's complete adjuvant for first immunization and Freund's incomplete adjuvant for boosted immunization). The antigen was injected into rabbits at 2 sites in the back, 2 sites in the groin, and 2 sites in the armpit. Boosts were given every 2 wk after first immunization. Blood samples were drawn regularly and the titer was checked.

\section{Preparation of a Polyclonal Antibody Specific to Cronobacter spp.}

The antibody titer of the immunized rabbit serum was determined by an indirect ELISA and the blood of the rabbit was isolated when the titer reached 1:100,000. The optimized indirect ELISA process was according to our previous study (Chen et al., 2016). One hundred microliters per well of C. sakazakii culture with concentration of $10^{7} \mathrm{cfu} / \mathrm{mL}$ was coated on a $96-$ well plate by coating buffer (carbonate sodium buffer, $\mathrm{pH} 9.6$ ) at $4^{\circ} \mathrm{C}$ overnight. After washing in washing buffer (0.1 M PBS buffer and 0.05\% Tween 20, $200 \mu \mathrm{L} /$ well) 3 times, the plate was blocked with BSA solution $(1 \% \mathrm{BSA}$, wt $/ \mathrm{vol})$ at $37^{\circ} \mathrm{C}$ for $60 \mathrm{~min}$. Immunized rabbit serum was serial diluted and then added to wells (100 $\mu \mathrm{L} /$ well) as primary antibody after washing step and horseradish peroxidase-conjugated goat anti-rabbit $\operatorname{IgG}(1: 10,000, \mathrm{vol} / \mathrm{vol})$ was used as secondary antibody (100 $\mu \mathrm{L} /$ well). Finally, $100 \mu \mathrm{L}$ of tetramethylbenzidine was added per well and $50 \mu \mathrm{L}$ of $2 M \mathrm{H}_{2} \mathrm{SO}_{4}$ was added to terminate the reaction after incubation at $25^{\circ} \mathrm{C}$ for $10 \mathrm{~min}$. The absorbance values at $450 \mathrm{~nm}$ wavelength were measured.

The rabbit anti-serum was prepared by centrifugation at $10,000 \times g$ for $10 \mathrm{~min}$ at $4^{\circ} \mathrm{C}$ after $24 \mathrm{~h}$ to allow for clotting. The polyclonal antibody was obtained from anti-serum by ammonium sulfate fractionation and fur- ther purified by HiTrap Protein G HP (GE Healthcare, Chicago, IL). After desalination by HiTrap desalting (GE Healthcare), $\mathrm{NaN}_{3}$ was added to the purified antibody at a final concentration of $0.02 \%$. The antibody was stored at $4^{\circ} \mathrm{C}$ and later analyzed by SDS-PAGE and an indirect ELISA.

\section{Conjugation of the Polyclonal Antibody to IMB}

The purified polyclonal antibody specific to Cronobacter was conjugated to magnetic beads according to the protocol of Dynabeads M-280 Tosylactivated (Invitrogen, Thermo Fisher Scientific, Waltham, MA). The magnetic beads were resuspended by vortexing and placed on a magnet for 2 min to allow the beads to gather at bottom of the tube. The supernatant was removed, and the magnetic beads in the tube were washed with $130 \mu \mathrm{L}$ each of buffer A (0.1 $M$ borate buffer, $\mathrm{pH}$ 9.5) and buffer B (0.1 M Na-phosphate buffer, $\mathrm{pH} 7.4)$. Twenty microliters of the purified polyclonal antibody $(20 \mu \mathrm{g} / \mu \mathrm{L})$ and $100 \mu \mathrm{L}$ of buffer $\mathrm{C}(3 \mathrm{M}$ ammonium sulfate in buffer $\mathrm{A}$ or $\mathrm{B}$ ) were added to the tube and mixed lightly with the magnetic beads. After incubation for 12 to $18 \mathrm{~h}$, the tube was placed on a magnet for 2 min and the supernatant was removed. The sites on the beads that had not been bound with the antibody were blocked with $1 \mathrm{~mL}$ of buffer D (PBS with $0.5 \%$ [wt/vol] BSA, pH 7.4). The magnetic beads bound with antibody were washed 3 times with buffer E (PBS with $0.1 \%$ [wt/vol] BSA, $\mathrm{pH} 7.4$ ) and resuspended with 240 $\mu \mathrm{L}$ of buffer E.

\section{Optimized IMS-PCR Conditions}

Twenty microliters of the prepared immunomagnetic bead suspension was added to a 1.5-mL tube and mixed with $1 \mathrm{~mL}$ of bacterial cell culture. The tube was incubated for $30 \mathrm{~min}$ at $37^{\circ} \mathrm{C}$ at $180 \mathrm{rpm}$ and placed on a magnet for $2 \mathrm{~min}$. The supernatant was removed and beads were washed 3 times with $1 \mathrm{~mL}$ of buffer $\mathrm{D}$. The immunomagnetic beads were then resuspended in 100 $\mu \mathrm{L}$ of normal saline.

The primers (Esakf: 5'-GCTYTGCTGACGAGTGGCGG-3'; Esakr: 5'-ATCTCTGCAGGATTCTCTGG-3') used in the IMS-PCR method were from a previous study (Lehner et al., 2004). The PCR amplification was carried out in a $25-\mu \mathrm{L}$ reaction mixture containing $12.5 \mu \mathrm{L}$ of $2 \times$ Taq Master (Vazyme Biotech Co., Jiangsu, China), $9.5 \mu \mathrm{L}$ of sterile distilled water, $1 \mu \mathrm{L}$ of each primer $(0.25 \mu M)$, and $2 \mu \mathrm{L}$ of the immunomagnetic beads. The PCR conditions included an initial incubation at $94^{\circ} \mathrm{C}$ for $2 \mathrm{~min}$, followed by 30 cycles of $94^{\circ} \mathrm{C}$ for $30 \mathrm{~s}, 58^{\circ} \mathrm{C}$ for $40 \mathrm{~s}, 72^{\circ} \mathrm{C}$ for $1 \mathrm{~min}$, 
and the final step of $72^{\circ} \mathrm{C}$ for $7 \mathrm{~min}$. The PCR products were analyzed by agarose gel electrophoresis and visualized using a UV transilluminator.

\section{Specificity Test and Sensitivity in Pure Culture of the IMS-PCR Method}

A total of 18 bacterial strains were cultured in appropriate medium overnight at $37^{\circ} \mathrm{C}$ and $180 \mathrm{rpm}$. One milliliter of each culture was sampled and detected by IMS-PCR.

The C. sakazakii CICC 21560 culture was serially diluted 10-fold with $0.9 \%$ normal saline, and the cell concentration was determined by plating on LB agar and counting the colonies. The cells from $1 \mathrm{~mL}$ of $C$. sakazakii CICC 21560 culture at different dilutions were isolated by IMS and detected by the plate cultivation method and PCR.

\section{Testing for IMS-PCR Interference Using E. coli in Artificially Contaminated PIF}

Cronobacter sakazakii CICC21560 and E. coli CMCC (National Center for Medical Culture Collections, Beijing, China) 23657 were grown in $\mathrm{LB}$ broth at $37^{\circ} \mathrm{C}$ overnight. Their cell concentrations were determined by serially diluting the cultures 10 -fold, plating on LB agar, and counting the colonies.

Twenty-five grams of PIF was mixed with $225 \mathrm{~mL}$ of nutrient broth. Then, $8 \mathrm{~mL}$ of nutrient broth-PIF mixture, $1 \mathrm{~mL}$ of $E$. coli CMCC 23657 culture $\left(10^{8} \mathrm{cfu} /\right.$ $\mathrm{mL}$ ), and $1 \mathrm{~mL}$ of C. sakazakii CICC 21560 culture $\left(10^{2}-10^{8} \mathrm{cfu} / \mathrm{mL}\right)$ were mixed. Sterile water was used as a negative control. Cronobacter muytjensii CICC 21563 and C. sakazakii CICC 21560 were used as positive controls. The cell culture mixture was detected by the IMS-PCR method developed in this study.

\section{Use of the IMS-PCR Method for Detection of C. Sakazakii in Artificially Contaminated PIF}

An overnight culture of C. sakazakii CICC 21560 was serially diluted 10-fold, and the cell concentration was determined by the plate counting method. Afterward, $25 \mathrm{~g}$ of PIF was mixed with $225 \mathrm{~mL}$ of nutrient broth; $1 \mathrm{~mL}$ of C. sakazakii CICC 21560 culture $\left(5.2 \times 10^{6}\right.$ to $5.2 \times 10^{1} \mathrm{cfu} / \mathrm{mL}$ ) was added to $9 \mathrm{~mL}$ of the nutrient broth-PIF mixture. One milliliter of artificially contaminated PIF was separately sampled and detected with IMS-PCR directly.

Similarly, $1 \mathrm{~mL}$ of C. sakazakii CICC21560 culture $\left(5.2 \times 10^{6}\right.$ to $\left.5.2 \times 10^{2} \mathrm{cfu} / \mathrm{mL}\right)$ was added to $9 \mathrm{~mL}$ of the nutrient broth-PIF mixture. After culturing for $8 \mathrm{~h}$ at $37^{\circ} \mathrm{C}, 1 \mathrm{~mL}$ of cell culture was removed and detected by IMS-PCR.

\section{Application of the IMS-PCR Method in Various Food Samples}

Seventy food samples, including 17 PIF samples, infant formula foods (9 rice flour samples, 2 noodle samples, and 6 cookie samples), 6 formulated milk powder samples for pregnant and breastfeeding mothers, and 30 cereals and their product samples were purchased from local grocery stores and supermarkets in Nanjing. Twenty-five grams of each sample was mixed with $225 \mathrm{~mL}$ of nutrient broth and incubated at $37^{\circ} \mathrm{C}$ and $180 \mathrm{rpm}$ for $8 \mathrm{~h}$. One milliliter of each culture was sampled twice and detected by IMS-PCR and culture-based method from ISO standard (ISO, 2006), respectively. The rest of the immunomagnetic beads of positive samples were spread on solid medium and isolates were recovered (the isolates were detected by primers of IMS-PCR again). The target strains were further identified by $16 \mathrm{~S}$ rDNA identification.

\section{RESULTS AND DISCUSSION}

\section{Serum Purification of the Polyclonal Antibody Specific to Cronobacter}

The sequence of ompA was relatively conserved throughout the Cronobacter genus but was not conserved compared with other genera of common foodborne pathogens (Chen et al., 2016). Thus, ompA from C. sakazakii was used to prepare the antibody. The crude polyclonal antibody obtained by ammonium sulfate precipitation was further purified by HiTrap Protein G HP (Figure 1A) and analyzed by SDSPAGE. The result of SDS-PAGE showed that the purified antibody consisted of 2 bands at approximately 25 $\mathrm{kDa}$ (light chain) and $55 \mathrm{kDa}$ (heavy chain; Figure 1B). Also, 2 impurity bands (red box in Figure 1B) had been removed after being purified by HiTrap Protein G HP. Therefore, the purified polyclonal antibody had higher purity than the product of saturated ammonium sulfate precipitation. The titer of antibody was tested by an indirect ELISA and was over 1:80,000 (Figure 1C).

The specificity of the polyclonal antibody was tested and showed very strong reactivity with Cronobacter, weak cross-reactivity with $S$. enteritidis and $E$. coli BL21 (DE3), and no reactivity with other bacteria tested (Table 1). Considering that PCR is also used in the IMS-PCR detection method, the weak crossreactivity could reduce false-negative results, while not increasing false positives in the final detection. Finally, the antibody was conjugated to magnetic beads. 


\section{IMS-PCR Procedure}

The polyclonal antibody was added to the surface of magnetic beads. The IMS and PCR together create the IMS-PCR method to detect Cronobacter spp. The primers used in IMS-PCR are widely used (Lehner et al., 2004; Caubilla-Barron et al., 2007; Cawthorn and Witthuhn, 2008) and better identify the Cronobacter genus as compared with other specific primers (Cawthorn et al., 2008). The PMS-PCR must first lyse the bacterial cell wall to release the genomic DNA, which is then isolated by a DNA probe targeting $16 \mathrm{~S}$ rRNA

A

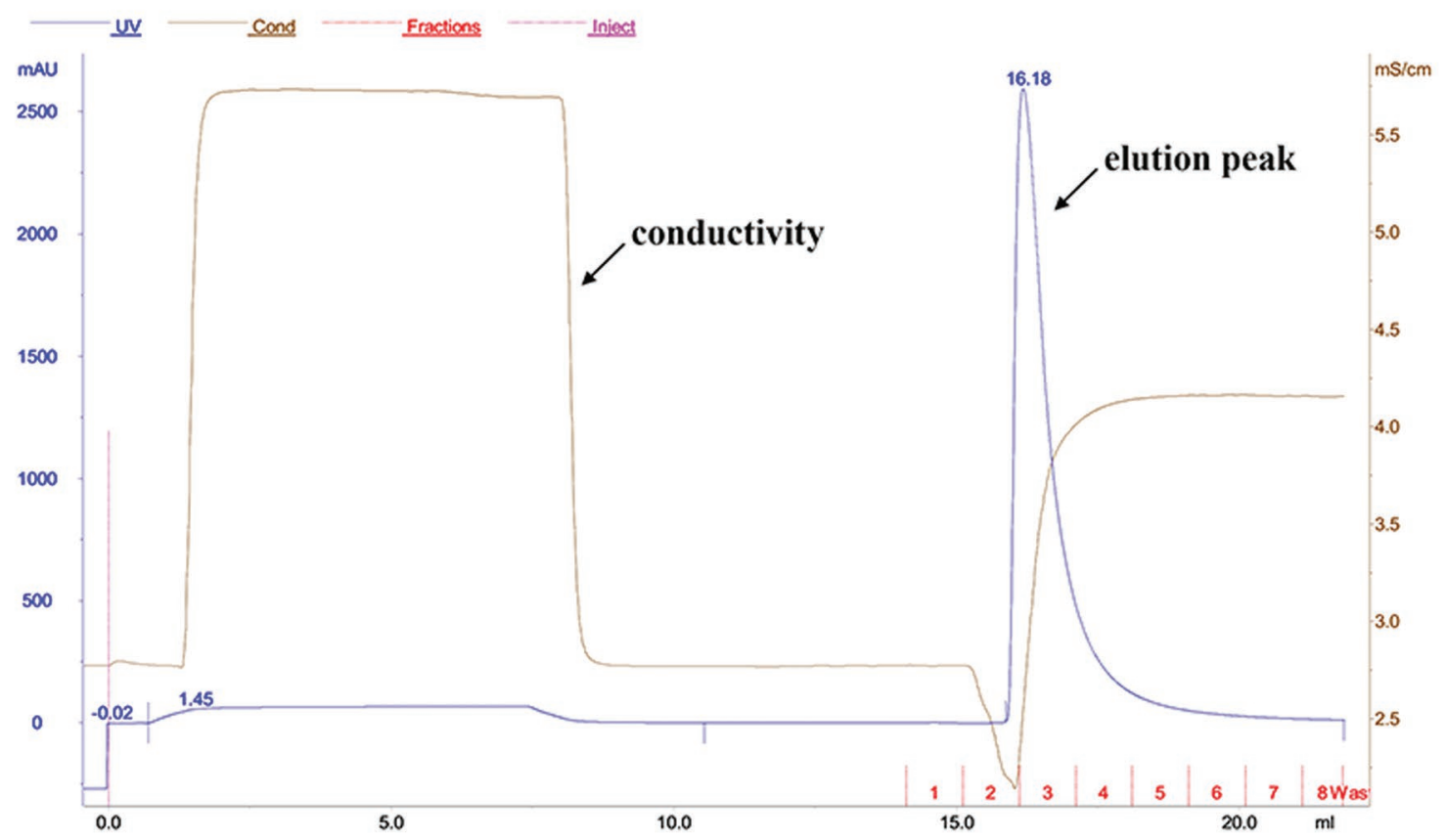

B

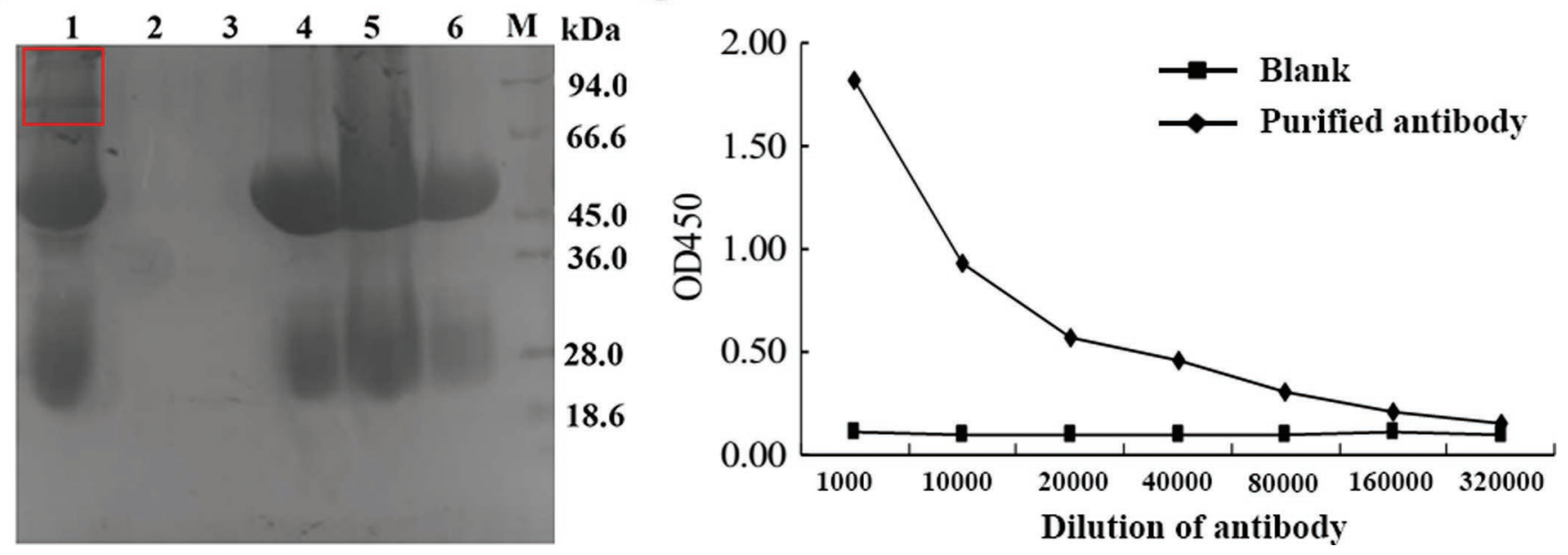

Figure 1. Sodium dodecyl sulfate-PAGE analysis of the purified rabbit anti-ompA (outer membrane protein A) polyclonal antibody and the antibody titers. (A) Elution profile of polyclonal antibody purified from a HiTrap Protein G HP column (GE Healthcare, Chicago, IL); (B) SDS-PAGE analysis of the rabbit anti-ompA polyclonal antibody purified by ammonium sulfate and HiTrap Protein G HP. Lane M: Protein molecular weight marker (kDa); lane 1: polyclonal antibody purified by saturated ammonium sulfate; the 2 bands in the white (red) box were impurities that had not been removed by ammonium sulfate precipitation; lanes 2 to 6: purified fractions 1 to 5 in panel A. The heavy chain and light chain were approximately 55 and $25 \mathrm{kDa}$, respectively; $(\mathrm{C})$ titer of rabbit anti-ompA polyclonal antibody. OD450 = optical density at $450 \mathrm{~nm}$. Color version available online. 


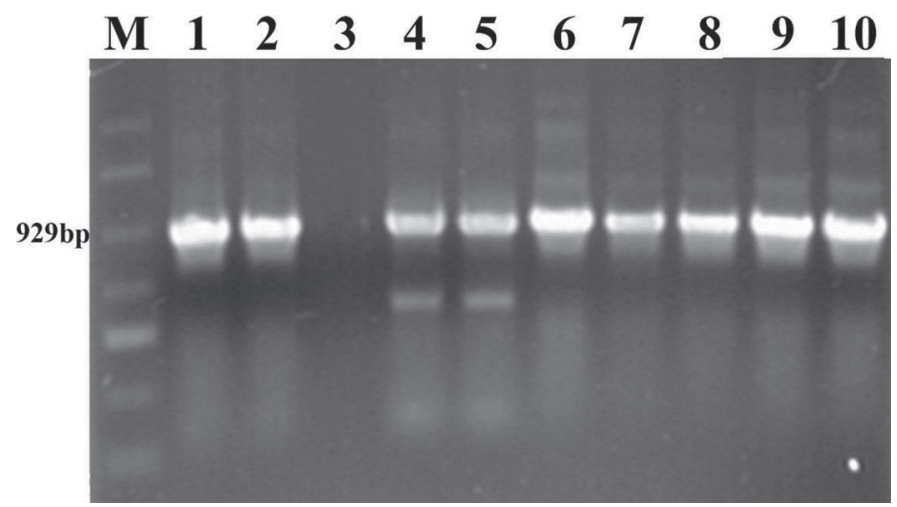

Figure 2. Detection of Cronobacter sakazakii using the immunomagnetic separation (IMS) PCR method in the presence of Escherichia coli American Type Culture Collection (ATCC) 35150. Lane M: 100bp DNA ladder; lane 1: positive control [C. sakazakii China Center of Industrial Culture Collection (CICC) 21560]; lane 2: positive control (Cronobacter muytjensii CICC 21563); lane 3: negative control (samples of powdered infant formula without inoculation); lane 4 to lane 10: artificially contaminated powdered infant formula with different levels of $C$. sakazakii $\left(10^{7}-10^{1} \mathrm{cfu} / \mathrm{mL}\right)$ and a fixed level of $E$. coli CMCC (National Center for Medical Culture Collections, Beijing, China) $23657\left(10^{7} \mathrm{cfu} / \mathrm{mL}\right)$.

gene sequence conjugated to magnetic beads (Xu et al., 2014a). Compared with this method, IMS-PCR does not need to lyse bacterial cells during IMS; therefore, the entire bacterial cell can be used for further study.

\section{Sensitivity Evaluation and Specificity Test of IMS-PCR}

A total of 18 bacterial strains were used to test the specificity of the IMS-PCR method. Only target bands appeared on a gel run of 6 Cronobacter spp., and no target bands appeared on gel of other genus bacterial strains (Table 1). Therefore, the IMS-PCR method developed in this study has good specificity. Compared with the PMS-PCR method (Xu et al., 2014a), our specificity test covers common foodborne pathogens and the main species of Cronobacter spp., except $C$. condimentii, which has only been isolated once before at this time.
The capture rate of the immunomagnetic beads trended down as the cell concentration of $C$. sakazakii went down. When the cell concentration reached $5.2 \times$ $10^{2} \mathrm{cfu} / \mathrm{mL}$, the cell concentration could not be measured by the plate cultivation method. However, the PCR still showed a positive result. Therefore, the lower detection limit for pure cell culture of the IMS-PCR method was $5.2 \times 10^{2} \mathrm{cfu} / \mathrm{mL}$ (Table 2). The PMSPCR method in a previous report (Xu et al., 2014a) showed a lower detection limit $\left(10^{1} \mathrm{cfu} / \mathrm{mL}\right)$.

\section{Testing for IMS-PCR Interference with a High Cell Concentration of E. Coli in Artificially Contaminated PIF}

Genomic DNA from non-Cronobacter bacteria may affect IMS-PCR detection of Cronobacter and lead to a false-positive result. Hence, C. sakazakii CICC21560 with a cell concentration of $5.2 \times 10^{5}$ to $5.2 \times 10^{0} \mathrm{cfu} /$ $\mathrm{mL}$ was used as a template, and E. coli CMCC 23657 with a cell concentration of $10^{7} \mathrm{cfu} / \mathrm{mL}$ was used as background to evaluate possible interference. As shown in Figure 2, all target bands appeared, indicating that the IMS-PCR method developed in this study was not affected by genomic DNA of other bacteria (E. coli in this case).

\section{Application and Evaluation of the IMS-PCR Method in Artificially Contaminated PIF}

Food samples may contain inhibitors for the IMS and PCR reactions. Hence, the detection limit of IMSPCR in artificially contaminated PIF was determined. As shown in Figure 3A, the target band still appeared when the cell concentration of C. sakazakii was down to $5.2 \times 10^{2} \mathrm{cfu} / \mathrm{mL}$ in PIF, which was the same as the detection limit in pure cell culture. Correspondingly, the PMS-PCR method used in previous studies showed a higher detection limit of $10^{3} \mathrm{cfu} / \mathrm{mL}$ in artificially contaminated PIF (Xu et al., 2014a). Although the IMS-PCR detection limit for pure cell culture was higher than that of PMS-PCR, the detection limit of IMS-PCR in artificially contaminated PIF was lower

Table 2. Sensitivity of immunomagnetic separation PCR for Cronobacter sakazakii detection in pure culture

\begin{tabular}{lccc}
\hline $\begin{array}{l}\text { Initial number } \\
\text { of C. sakazakii (cfu) }\end{array}$ & $\begin{array}{c}\text { Capture number } \\
\text { of C. sakazakii (cfu) }\end{array}$ & $\begin{array}{c}\text { Capture } \\
\text { rate (\%) }\end{array}$ & $\begin{array}{c}\text { PCR } \\
\text { result }^{1}\end{array}$ \\
\hline $5.2 \times 10^{6}$ & $3.5 \times 10^{5}$ & 67.3 & + \\
$5.2 \times 10^{5}$ & $3.9 \times 10^{4}$ & 75 & + \\
$5.2 \times 10^{4}$ & $1.4 \times 10^{3}$ & 26.9 & + \\
$5.2 \times 10^{3}$ & 89 & 17.1 & + \\
$5.2 \times 10^{2}$ & $\mathrm{ND}$ & $\mathrm{ND}$ & + \\
$5.2 \times 10^{1}$ & $\mathrm{ND}$ & $\mathrm{ND}$ & $\mathrm{ND}$ \\
\hline
\end{tabular}




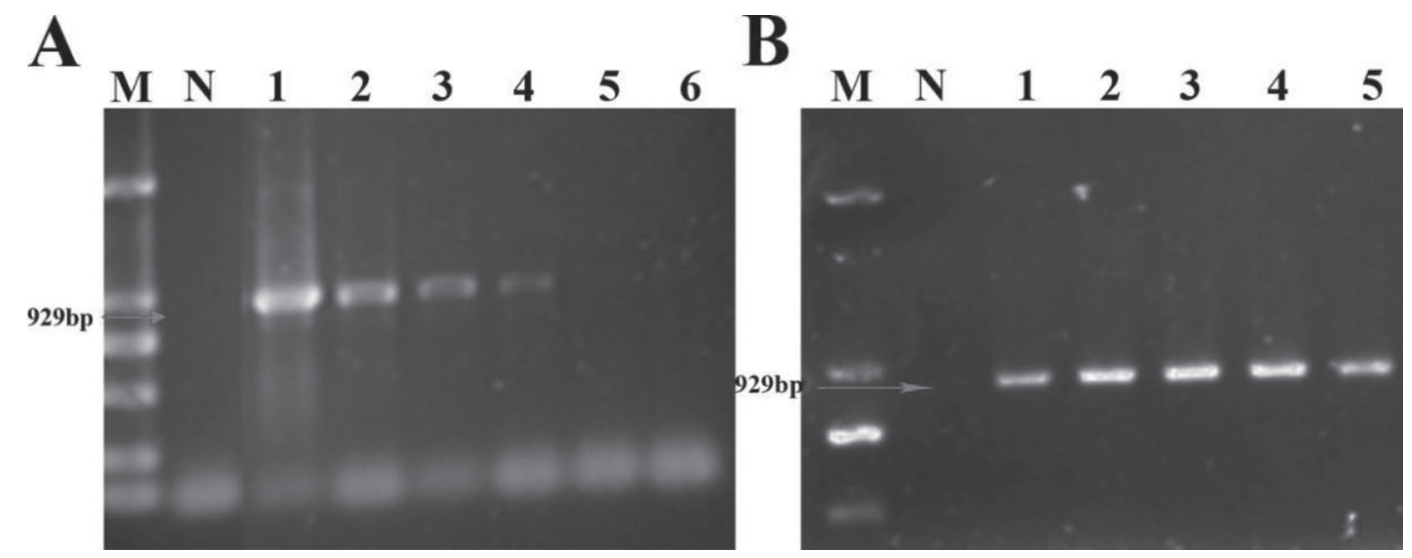

Figure 3. Sensitivity of immunomagnetic separation (IMS) PCR for Cronobacter sakazakii detection in artificially contaminated powdered infant formula (PIF) and detection of C. sakazakii after an 8-h enrichment step in artificially contaminated PIF. (A) Sensitivity of IMS-PCR for C. sakazakii detection in artificially contaminated PIF. Lane M: 100-bp DNA ladder; lane N: negative control (samples of PIF without inoculation); lane 1 to lane 6: artificially contaminated PIF with different levels of C. sakazakii $\left(5.2 \times 10^{5}\right.$ to $\left.5.2 \times 10^{0} \mathrm{cfu} / \mathrm{mL}\right)$. (B) Detection of $C$. sakazakii from artificially contaminated PIF samples using the IMS-PCR method after an 8-h enrichment step. Lane M: 100-bp DNA ladder; lane N: negative control (samples of PIF without inoculation); lane 1 to lane 5: artificially contaminated PIF with different levels of $C$. sakazakii $\left(5.2 \times 10^{5}\right.$ to $\left.5.2 \times 10^{1} \mathrm{cfu} / \mathrm{mL}\right)$.

than that of the PMS-PCR method. This indicated that the IMS-PCR method had a better ability to resist interference from inhibitors in the reaction. After $8 \mathrm{~h}$ of enrichment, all target bands on the gel were clear and bright, even when the initial cell density was 5.2 $\times 10^{1} \mathrm{cfu} / \mathrm{mL}$ (Figure 3B), which indicated that the detection limit IMS-PCR was lower than $5.2 \times 10^{1} \mathrm{cfu} /$ $\mathrm{mL}$. This detection limit is lower than the infection titer of Cronobacter $\left(10^{3}\right.$ or $10^{4} \mathrm{cfu}$; Wang et al., 2012); thus, this method could be applied to the detection of Cronobacter in PIF.

\section{Application of the IMS-PCR Method in Various Food Samples}

Most infectious cases of Cronobacter were associated with PIF, thus PIF was chosen as the main food sample for artificial contamination to test the detection methods outlined in previous reports (Park et al., 2012; Chen et al., 2014, 2015). However, several other foods may potentially be sources of Cronobacter during food preparation for infants. Hence, the IMS-PCR method was applied to the detection of actual food samples and culture-based methods served as a control. Nine food samples showed positive results for Cronobacter spp., including 1 infant food formula, 5 formulated milk powder for pregnant and breastfeeding mothers, and 3 dry cereal products (Table 3 ). The culture-based method showed slightly different results. The positive results for the culture-based method were from 1 infant food formula, 3 milk products for pregnant and breastfeeding mothers, and 5 dry cereals. Both the IMS-PCR method and the culture-based method had not detected Cronobacter spp. from the PIF. The 11 target bacterial

Table 3. Detection of Cronobacter spp. in various food samples by immunomagnetic separation (IMS) PCR and culture-based method

\begin{tabular}{|c|c|c|c|c|c|}
\hline \multirow[b]{2}{*}{ Sample category } & \multirow{2}{*}{$\begin{array}{c}\text { No. of } \\
\text { samples }\end{array}$} & \multicolumn{2}{|c|}{ IMS-PCR method } & \multicolumn{2}{|c|}{ Culture-based method } \\
\hline & & Positive & Negative & Positive & Negative \\
\hline \multicolumn{6}{|l|}{ Cereal foods } \\
\hline Corn meal (grain) & 6 & 0 & 6 & 1 & 5 \\
\hline Buckwheat meal (grain) & 2 & 1 & 1 & 1 & 1 \\
\hline Wheat meal (grain) & 3 & 0 & 3 & 0 & 3 \\
\hline Soybean meal & 2 & 0 & 2 & 0 & 2 \\
\hline Rice & 11 & 1 & 10 & 1 & 10 \\
\hline Black rice & 2 & 0 & 2 & 0 & 2 \\
\hline Pearl barley & 2 & 1 & 1 & 2 & 0 \\
\hline Glutinous millet & 2 & 0 & 2 & 0 & 2 \\
\hline Powered infant formula & 17 & 0 & 17 & 0 & 17 \\
\hline Formulated milk powder for pregnant and breastfeeding mothers & 6 & 5 & 1 & 3 & 3 \\
\hline Infant formula foods & 17 & 1 & 16 & 1 & 16 \\
\hline Total & 70 & 9 & 61 & 9 & 61 \\
\hline
\end{tabular}


Table 4. Origin and strain number of presumptive Cronobacter isolates screened from foods

\begin{tabular}{|c|c|c|c|c|c|}
\hline $\begin{array}{l}\text { Strain } \\
\text { number }\end{array}$ & Sample & Origin & $\begin{array}{l}\text { IMS-PCR } \\
\text { method }^{1}\end{array}$ & $\begin{array}{l}\text { Culture-based } \\
\text { method }^{1}\end{array}$ & 16S rDNA sequencing \\
\hline$\overline{\mathrm{C} 1}$ & $\mathrm{~S} 5$ & Buckwheat meal & + & + & Cronobacter spp. \\
\hline $\mathrm{C} 2$ & S19 & Pearl barley & + & + & Cronobacter spp. \\
\hline $\mathrm{C} 4$ & $\mathrm{~S} 24$ & Pearl barley & - & + & Klebsiella pneumoniae \\
\hline C5 & $\mathrm{S} 29$ & Rice & + & + & Cronobacter spp. \\
\hline C6 & S39 & Milk powder ${ }^{2}$ & + & + & Cronobacter spp. \\
\hline $\mathrm{C} 10$ & $\mathrm{~S} 50$ & Milk powder ${ }^{2}$ & + & - & Cronobacter spp. \\
\hline $\mathrm{C} 11$ & S66 & Infant formula ${ }^{3}$ & + & + & Cronobacter spp. \\
\hline
\end{tabular}

${ }^{1}+$, positive result; - , negative result. IMS $=$ immunomagnetic separation.

${ }^{2}$ Formulated milk powder for pregnant and breastfeeding mothers.

${ }^{3}$ Formulated noodle for infants.

strains were further identified by $16 \mathrm{~S}$ rDNA sequencing technology. The results (Table 4) showed that isolated strains $\mathrm{C} 1, \mathrm{C} 2$, and C5-C11 showed a similarity of $99 \%$ to C. sakazakii and isolated strains C3 and C4 showed 99\% similarity with Enterobacter hormaechei and Klebsiella pneumoniae, respectively. The IMS-PCR detection method showed no false-positive or false-negative results. Thus, IMS-PCR is a reliable method that could be applied to Cronobacter in foods.

\section{CONCLUSIONS}

In this study, a polyclonal antibody with high specificity to Cronobacter spp. was created and attached to the surface of magnetic beads to obtain immunomagnetic beads, which were then used to isolate Cronobacter spp. A specific pair of primers further identified the isolated cells. Thus, we developed an IMS-PCR method for Cronobacter spp. detection. To our knowledge, this is the first report of an IMS-PCR method for detecting Cronobacter spp. We evaluated the specificity of the IMS-PCR method, as well as its ability to avoid interference from off-target bacteria. This method's sensitivity and resistance to interference were determined in artificially contaminated PIF, as well as in actual food samples. These tests proved that the IMS-PCR detection method developed in this study is sensitive, rapid, and reliable and could be applied to the detection of Cronobacter in foods.

\section{ACKNOWLEDGEMENTS}

The work was supported by Natural Science Foundation of China (Grant No. 31401595), National Key Technology Support Program (2012BAK08807), and the Agricultural Science and Technology Innovation Fund of Jiangsu Province [CX(12)3087].

\section{REFERENCES}

Álvarez-Ordóñez, A., M. Begley, T. Clifford, T. Deasy, B. Collins, and C. Hill. 2014. Transposon mutagenesis reveals genes involved in osmotic stress and drying in Cronobacter sakazakii. Food Res. Int. 55:45-54.

Arseni, A., E. Malamou-Ladas, C. Koutsia, M. Xanthou, and E. Trikka. 1987. Outbreak of colonization of neonates with Enterobacter sakazakii. J. Hosp. Infect. 9:143-150.

Caubilla-Barron, J., E. Hurrell, S. Townsend, P. Cheetham, C. LocCarrillo, O. Fayet, M. F. Prere, and S. J. Forsythe. 2007. Genotypic and phenotypic analysis of Enterobacter sakazakii strains from an outbreak resulting in fatalities in a neonatal intensive care unit in France. J. Clin. Microbiol. 45:3979-3985.

Cawthorn, D. M., S. Botha, and R. C. Witthuhn. 2008. Evaluation of different methods for the detection and identification of Enterobacter sakazakii isolated from South African infant formula milks and the processing environment. Int. J. Food Microbiol. 127:129-138.

Cawthorn, D. M., and R. C. Witthuhn. 2008. Selective PCR detection of viable Enterobacter sakazakii cells utilizing propidium monoazide or ethidium bromide monoazide. J. Appl. Microbiol. 105:1178-1185.

Chen, F., X. Ming, X. Chen, M. Gan, B. Wang, F. Xu, and H. Wei. 2014. Immunochromatographic strip for rapid detection of Cronobacter in powdered infant formula in combination with silicacoated magnetic nanoparticles separation and 16S rRNA probe. Biosens. Bioelectron. 61:306-313.

Chen, H., and H. Zhuang. 2012. Determination of 3,4-dichlorinated biphenyl in soil samples by real-time immuno-PCR assay. J. Environ. Sci. (China) 24:2191-2197.

Chen, Q., T. Tao, X. Bie, F. Lu, Y. Li, and Z. Lu. 2016. Characterization of a single-chain variable fragment specific to Cronobacter spp. from hybridoma based on outer membrane protein A. J. Microbiol. Methods 129:136-143.

Chen, Q., T. Tao, X. Bie, Y. Lu, F. Lu, L. Zhai, and Z. Lu. 2015. Mining for sensitive and reliable species-specific primers for PCR for detection of Cronobacter sakazakii by a bioinformatics approach. J. Dairy Sci. 98:5091-5101.

Chiang, Y. C., H. Y. Tsen, H. Y. Chen, Y. H. Chang, C. K. Lin, C. Y. Chen, and W. Y. Pai. 2012. Multiplex PCR and a chromogenic DNA macroarray for the detection of Listeria monocytogenes, Staphylococcus aureus, Streptococcus agalactiae, Enterobacter sakazakii, Escherichia coli O157:H7, Vibrio parahaemolyticus, Salmonella spp. and Pseudomonas fluorescens in milk and meat samples. J. Microbiol. Methods 88:110-116.

Derzelle, S., F. Dilasser, V. Maladen, N. Soudrie, A. Leclercq, B. Lombard, and V. Lafarge. 2007. Comparison of three chromogenic media and evaluation of two molecular-based identification systems for the detection of Enterobacter sakazakii from environmental 
samples from infant formulae factories. J. Food Prot. 70:16781684.

Druggan, P., and C. Iversen. 2009. Culture media for the isolation of Cronobacter spp. Int. J. Food Microbiol. 136:169-178.

Fedio, W. M., K. C. Jinneman, K. J. Yoshitomi, R. Zapata, C. N. Wendakoon, P. Browning, and S. D. Weagant. 2011. Detection of E. coli $\mathrm{O} 157: \mathrm{H} 7$ in raw ground beef by Pathatrix immunomagnetic-separation, real-time PCR and cultural methods. Int. J. Food Microbiol. 148:87-92.

Friedemann, M. 2009. Epidemiology of invasive neonatal Cronobacter (Enterobacter sakazakii) infections. Eur. J. Clin. Microbiol. Infect. Dis. 28:1297-1304.

Hassan, A. A., O. Akineden, C. Kress, S. Estuningsih, E. Schneider, and E. Usleber. 2007. Characterization of the gene encoding the $16 \mathrm{~S}$ rRNA of Enterobacter sakazakii and development of a speciesspecific PCR method. Int. J. Food Microbiol. 116:214-220.

Healy, B., S. Cooney, S. O'Brien, C. Iversen, P. Whyte, J. Nally, J. J. Callanan, and S. Fanning. 2010. Cronobacter (Enterobacter sakazakii): An opportunistic foodborne pathogen. Foodborne Pathog. Dis. $7: 339-350$.

ISO. 2006. ISO/TS 22964:2006. Milk and milk products-Detection of Enterobacter sakazakii. International Organization for Standardization, Geneva, Switzerland.

Iversen, C., A. Lehner, N. Mullane, J. Marugg, S. Fanning, R. Stephan, and H. Joosten. 2007. Identification of "Cronobacter" spp. (Enterobacter sakazakii). J. Clin. Microbiol. 45:3814-3816.

Iversen, C., N. Mullane, B. McCardell, B. D. Tall, A. Lehner, S. Fanning, R. Stephan, and H. Joosten. 2008. Cronobacter gen. nov., a new genus to accommodate the biogroups of Enterobacter sakazakii, and proposal of Cronobacter sakazakii gen. nov., comb. nov., Cronobacter malonaticus sp. nov., Cronobacter turicensis sp. nov., Cronobacter muytjensii sp. nov., Cronobacter dublinensis sp. nov., Cronobacter genomospecies 1, and of three subspecies, Cronobacter dublinensis ssp. dublinensis ssp. nov., Cronobacter dublinensis ssp. lausannensis ssp. nov. and Cronobacter dublinensis ssp. lactaridi ssp. nov. Int. J. Syst. Evol. Microbiol. 58:1442-1447.

Iversen, C., M. Waddington, S. L. On, and S. Forsythe. 2004. Identification and phylogeny of Enterobacter sakazakii relative to Enterobacter and Citrobacter species. J. Clin. Microbiol. 42:5368-5370.

Jenikova, G., J. Pazlarova, and K. Demnerova. 2000. Detection of Salmonella in food samples by the combination of immunomagnetic separation and PCR assay. Int. Microbiol. 3:225-229.

Joseph, S., E. Cetinkaya, H. Drahovska, A. Levican, M. J. Figueras, and S. J. Forsythe. 2012. Cronobacter condimenti sp. nov., isolated from spiced meat, and Cronobacter universalis sp. nov., a species designation for Cronobacter sp. genomospecies 1, recovered from a leg infection, water and food ingredients. Int. J. Syst. Evol. Microbiol. 62:1277-1283.

Joseph, S., and S. J. Forsythe. 2012. Insights into the emergent bacterial pathogen Cronobacter spp., generated by multilocus sequence typing and analysis. Front. Microbiol. 3:397.

Joshi, S. S., A. B. Howell, and D. H. D'Souza. 2014. Cronobacter sakazakii reduction by blueberry proanthocyanidins. Food Microbiol. 39:127-131.

Lehner, A., T. Tasara, and R. Stephan. 2004. 16S rRNA gene based analysis of Enterobacter sakazakii strains from different sources and development of a PCR assay for identification. BMC Microbiol. 4:43.

Leon-Velarde, C. G., L. Zosherafatein, and J. A. Odumeru. 2009. Application of an automated immunomagnetic separation-enzyme immunoassay for the detection of Salmonella enterica subspecies enterica from poultry environmental swabs. J. Microbiol. Methods 79:13-17.

Li, Y., L. Cao, C. Zhang, Q. Chen, F. Lu, X. Bie, and Z. Lu. 2013. Development and evaluation of a PCR-ELISA assay for the detection and quantification of Cronobacter spp. Int. Dairy J. 33:27-33.

Liu, Y., X. Cai, X. Zhang, Q. Gao, X. Yang, Z. Zheng, M. Luo, and X. Huang. 2006. Real time PCR using TaqMan and SYBR Green for detection of Enterobacter sakazakii in infant formula. J. Microbiol. Methods 65:21-31.

Mohan Nair, M. K., and K. S. Venkitanarayanan. 2006. Cloning and sequencing of the ompA gene of Enterobacter sakazakii and development of an ompA-targeted PCR for rapid detection of Enterobacter sakazakii in infant formula. Appl. Environ. Microbiol. 72:2539-2546.

Park, S., S. Shukla, Y. Kim, S. Oh, S. Hun Kim, and M. Kim. 2012. Development of sandwich enzyme-linked immunosorbent assay for the detection of Cronobacter muytjensii (formerly called Enterobacter sakazakii). Microbiol. Immunol. 56:472-479.

Seo, K. H., and R. E. Brackett. 2005. Rapid, specific detection of Enterobacter sakazakii in infant formula using a real-time PCR assay. J. Food Prot. 68:59-63.

Townsend, S., E. Hurrell, and S. Forsythe. 2008. Virulence studies of Enterobacter sakazakii isolates associated with a neonatal intensive care unit outbreak. BMC Microbiol. 8:64.

Tram, L. L. T., C. Cao, J. Høgberg, A. Wolff, and D. D. Bang. 2012. Isolation and detection of Campylobacter jejuni from chicken fecal samples by immunomagnetic separation-PCR. Food Contr. 24:23-28.

Wadud, S., C. G. Leon-Velarde, N. Larson, and J. A. Odumeru. 2010. Evaluation of immunomagnetic separation in combination with ALOA Listeria chromogenic agar for the isolation and identification of Listeria monocytogenes in ready-to-eat foods. J. Microbiol. Methods 81:153-159.

Wang, X., C. Zhu, X. Xu, and G. Zhou. 2012. Real-time PCR with internal amplification control for the detection of Cronobacter spp. (Enterobacter sakazakii) in food samples. Food Contr. 25:144-149.

$\mathrm{Xu}, \mathrm{F}$., P. Li, X. Ming, D. Yang, H. Xu, X. Wu, N. P. Shah, and H. Wei. 2014a. Detection of Cronobacter species in powdered infant formula by probe-magnetic separation PCR. J. Dairy Sci. 97:60676075.

Xu, X., Y. Zhang, M. Shi, W. Sheng, X. Du, M. Yuan, and S. Wang. 2014b. Two novel analytical methods based on polyclonal and monoclonal antibodies for the rapid detection of Cronobacter spp.: Development and application in powdered infant formula. LwtFood Sci. Technol. 56:335-340.

Zheng, Q., M. Miks-Krajnik, Y. Yang, W. Xu, and H. G. Yuk. 2014. Real-time PCR method combined with immunomagnetic separation for detecting healthy and heat-injured Salmonella Typhimurium on raw duck wings. Int. J. Food Microbiol. 186:6-13. 